\title{
Evaluating the efficacy of commercially avaliable aflatoxin binders for decreasing the effects of aflatoxicosis on Pacific white
} shrimp Litopenaeus vannamei

\author{
Evaluación de secuestrantes comerciales de aflatoxinas para reducir la aflatoxicosis en camarón blanco Litopenaeus vannamei \\ Mireya Tapia-Salazar, Oscar D. García-Pérez, Martha G. Nieto-López, David A. Villarreal-Cavazos, J. Gamboa-Delgado, \\ L. Elizabeth Cruz-Suárez and Denis Ricque-Marie
}

Universidad Autónoma de Nuevo León, Facultad de Ciencias Biológicas, Departamento de Ecología, Programa Maricultura. Ciudad Universitaria. Apdo. Postal F-67, San Nicolás de los Garza, Nuevo León, 66450, México e-mail: mailto:mireya.tapias|@uanl.edu.mx

Recibido: 27 de junio de 2016.

Aceptado: 29 de agosto de 2017.

Tapia-Salazar M., 0. D. García-Pérez, M. G. Nieto-López, D. A. Villarreal-Cavazos, J. Gamboa-Delgado, L. E. Cruz-Suárez and D. Ricque-Marie. 2017. Evaluating the efficacy of commercially available aflatoxin binders for decreasing the effects of aflatoxicosis on Pacific white shrimp Litopenaeus vannamei. Hidrobiológica 27 (3): 411-418. D0I: 10.24275/uam/izt/dcbs/hidro/2017v27n3/Tapia

\begin{abstract}
Background. Feeding aflatoxin-contaminated diets to shrimp juveniles reduces feed intake and growth rate, suppresses the immune system, causes hepatic lesions, and, in some cases, decreases survival rates. There is scarce information on the effectiveness of commercially available aflatoxin binders to reduce aflatoxicosis in shrimp. Goals. We investigated the effect of corn that was naturally contaminated with aflatoxins on the growth performance and nitrogen retention efficiency of white shrimp juveniles $L$. vannamei and the potential of three commercially available anti-aflatoxin additives. Methods. 20 tanks (60L) were stocked with 10 shrimp weighing $210 \pm 4 \mathrm{mg}$. Tanks were divided into five treatments with four replicates each. Shrimp were fed twice daily with either the contaminated diet (75 $\mathrm{\mu g} \mathrm{kg}^{-1}$ total aflatoxins), the contaminated diet supplemented with $2 \mathrm{~g} \mathrm{~kg}^{-1}$ Aflabalan $®, 2 \mathrm{~g} \mathrm{~kg}^{-1}$ Mycosorb $®$, and $2.5 \mathrm{~g} \mathrm{~kg}^{-1}$ Mycoflix plus $®$, or the uncontaminated diet to the control group for 42 days. Results. In terms of the diet containing aflatoxin without binding agents, the consumption, growth rate, and nitrogen-retention efficiency were significantly lower than the control treatment. The experimental diets did not affect the feed conversion ratio or survival rates in any treatment. The inclusion of any of the aflatoxin binders evaluated in the present study did not produce growth rates comparable to those of shrimp fed the uncontaminated diet. Conclusions. Aflatoxins decreased growth performance in a population of white shrimp juveniles L. vannamei. Although all the aflatoxin binders evaluated in this study caused an improvement, they were not effective in reversing all the negative effects caused by feeding aflatoxin-contaminated diets to white shrimp juveniles $L$. vannamei.
\end{abstract}

Key words: Aflatoxin, aflatoxin binders, Litopenaeus vannamei, shrimp.

\section{RESUMEN}

Antecedentes. La alimentación de dietas contaminadas con aflatoxina a juveniles de camarón reduce la ingesta de alimento, la tasa de crecimiento suprime el sistema inmunológico y causa lesiones hepáticas y en algunos casos, disminuye las tasas de sobrevivencia. Hay escasa información sobre la efectividad de los aglutinantes de aflatoxinas comercialmente disponibles para reducir la aflatoxicosis en camarones. Objetivos. Se investigó el efecto del maíz naturalmente contaminado con aflatoxinas sobre el rendimiento de crecimiento y la eficiencia de retención de nitrógeno de juveniles de camarón blanco $L$. vannamei y el potencial de tres aditivos anti-aflatoxina comercialmente disponibles. Métodos. 20 tanques (60L) fueron almacenados con 10 camarones con un peso de $210 \pm 4 \mathrm{mg}$. Los tanques se dividieron en cinco tratamientos con cuatro repeticiones cada uno. Los camarones fueron alimentados dos veces al día con la dieta contaminada (75 $\mu \mathrm{g} \mathrm{kg}^{-1}$ de aflatoxinas totales), la dieta contaminada suplementada con $2 \mathrm{~g} \mathrm{~kg}^{-1}$ de Aflabalan $®, 2 \mathrm{~g} \mathrm{~kg}^{-1} \mathrm{de}$ Mycosorb® y 2,5 g kg-1 de Mycoflix plus $®$, y la dieta no contaminada como grupo control durante 42 días. Resultados. Para la dieta que contenía aflatoxina sin agentes secuestrantes, el consumo, la tasa de crecimiento y la eficiencia de retención de nitrógeno fueron significativamente menores que el tratamiento de control. Las dietas experimentales no afectaron la tasa de conversión alimenticia ni las tasas de supervivencia en ningún tratamiento. La inclusión de cualquiera de los aglutinantes de aflatoxinas evaluados en el presente estudio no produjo tasas de crecimiento comparables a las de Ios camarones alimentados con la dieta no contaminada. Conclusiones. Las aflatoxinas disminuyeron el rendimiento de crecimiento en una población de juveniles de camarón blanco L. vannamei. Aunque todos los aglutinantes de aflatoxinas evaluados en este estudio causaron una mejora, no fueron eficaces para revertir todos los efectos negativos causados por la alimentación de dietas contaminadas con aflatoxina a juveniles de camarón blanco L. vannamei.

Palabras clave: Aflatoxinas, camarón, Litopenaeus vannamei, secuestrante de aflatoxinas. 


\section{INTRODUCTION}

The addition of plant-derived feedstuffs to aquaculture dietary formulas is an alternative for producing cost-effective feeds. However, at high levels these formulas produce some side effects triggered by the presence of substances, such as mycotoxins, that may reduce the animal's performance. Research has shown that feeding aflatoxin-contaminated diets to fish and shrimp reduces feed intake and growth performance, suppresses the immune system, and causes hepatic lesions (Arunlertaree et al., 2007; Gopinath \& Raj, 2009; Mohapatra et al., 2011; Arana et al., 2011; Tapia-Salazar et al., 2012; García-Pérez et al., 2013; Zeng et al., 2015). This occurs even at low levels (Tapia-Salazar et al., 2012; García-Pérez et al., 2013; Zeng et al., 2015). In terrestrial animals, the supplementation of aluminosilicates, biotransformation agents, or antioxidant compounds neutralize the impact caused by the consumption of diets containing mycotoxins (Surai \& Dvorska, 2005; Kolosova, \& Stroka, 2011; Gowda et al., 2013). In aquatic organisms, particularly fish, some studies have shown that some of the negative effects caused by the presence of mycotoxins are successfully reverted by including aluminosilicates, cell walls from yeast, glucomannan, or plant extracts (Sahoo et al., 2003; El-Barabay \& Mehrim 2009; Mahfouz, 2015). Conversely, other studies in which aluminosilicates were supplemented in diets that subsequently were fed to shrimp did not show promising results (Suppadit et al., 2006; Arunlertaree et al., 2007; García-Pérez et al., 2013). For some time, yeast has been used as a supplement in diets intended for consumption by terrestrial and aquatic animals in order to enhance their immune response as measured by the respective parameters (Ringø et al., 2012; Cheng et al., 2014). Recently, it was demonstrated that supplementation of yeast-derived products (Selim et al., 2014), alone or in combination with other mycotoxin binder/transforming products, significantly decreases mycotoxicosis in aquatic organisms (Hauptman et al., 2014). There is scarce information on the effectiveness of commercially available aflatoxin binders containing multicomponent-sequestering additives with regard to reducing aflatoxicosis in shrimp. Therefore, the aim of this study was to assess the adverse effects induced by the presence of aflatoxins on the growth rate, feed intake, feed conversion ratio, survival, and nitrogen retention efficiency. We also wanted to evaluate the potential of three commercially available anti-aflatoxin additives in preventing the negative effects caused by aflatoxin on a juvenile population of white shrimp Litopenaeus vannamei (Boone, 1931).

\section{MATERIAL AND METHODS}

Experimental design: The weight of two hundred white shrimp juveniles $L$. vannamei, characterized by a consistent body weight $(210 \pm 4$ $\mathrm{mg}$ ), were individually registered and randomly distributed in 20 groups containing ten shrimp each. Initial body weight distribution was equivalent in each group. Each dietary treatment was randomly assigned among the four tanks.

Experimental diets: Two control diets (aflatoxin-contaminated and non-contaminated diets) were formulated to contain $38 \%$ crude protein and $8 \%$ crude lipids. The aflatoxin levels included in this study were chosen based on a previous study (Tapia-Salazar et al., 2012), in which a significant decrease was observed on growth, feed intake, as well as the presence of histological damages without significantly affecting survival rates. A contaminated diet used as a control was formulated containing a total amount of $75 \mu \mathrm{g} \mathrm{kg}^{-1}$ aflatoxins $\left(7130 \mu \mathrm{g} \mathrm{kg}{ }^{-1}\right.$ total aflatoxin in the contaminated grain). The NuteK S.A. de C. V. company provided contaminated corn, according to a protocol previously described by Tapia-Salazar et al. (2012). The diet included $11.1 \%$ contaminated corn, mainly at the expense of wheat meal. Three more diets were prepared that included similar contamination levels and one of the following three aflatoxin binders that were tested: 1) Aflabalan $®$ third generation (SAGARPA registration number A-7853-00). This binder contains silica, maximum $65.60 \%$; sodium oxide, minimum $0.20 \%$; calcium oxide, minimum $3.90 \%$; sodium aluminum, minimum $6.65 \%$; and cell walls from the yeast Saccharomyces cerevisiae Meyen ex E. C. Hansen (Hansen, 1883 maximun 5\% (http://www.tecnicamineral.com. $\mathrm{mx} /$ divisiones.php?divisionproducto $=2 \&$ categoriaProducto $=15$ ). The recommended inclusion levels for use on terrestrial animals for preventive and corrective purposes range between 2 and $3 \mathrm{~kg} /$ ton of feed. 2) Mycosorb $®$ (SAGARPA registration number A-7569-051). This binder contains glucomannan cell walls from Saccharomyces cerevisiae and some varieties may contain cell walls from the microalga Chlorella vulgaris Beyerinck [Beijerinck]. (1890). https://nutricionanimal.info/ mycosorb-alltech/. The recommended inclusion levels for use on terrestrial animals range between 0.5 and $1.5 \mathrm{~kg} /$ ton without specifying preventive or corrective doses. 3) Mycofix plus $®$ (SAGARPA registration number A-7160-001). This binder contains bentonite plus the yeast Trichosporon mycotoxinivorans (Molnár et al., 2004) and algae extracts. Recommended inclusion levels for terrestrial animals range between 0.5 and 1.0 for preventive dosing, whereas $1.5-2.5 \mathrm{~kg} / \mathrm{ton}$ is recommended for corrective doses (https://nutricionanimal.info/download/ Mycofix-Plus-BBSH.pdf).

For aquatic species, no information was available on the optimal inclusion levels of aflatoxin binders for preventive and corrective dosing. Regarding Aflabalan $®$, a corrective level of $2 \mathrm{~g} \mathrm{~kg}^{-1}$ was used. Since there was a lack of information on terrestrial species and aquatic species, we followed the manufacturer's recommendations. Regarding Mycofix plus $®$, a corrective dose of $2.5 \mathrm{~g} \mathrm{~kg}^{-1}$ was selected, given its previous positive results on terrestrial species (Tapia-Salazar et al., 2010) as per the manufacturer's recommendations. In the case of Mycosorb®, the inclusion level was set at $2 \mathrm{~g} \mathrm{~kg}^{-1}$ because of insufficient results reported on terrestrial species at lower inclusion levels (Surai \& Dvorska, 2005; Boudergue et al., 2009; Kolosova \& Stroka, 2011; Gowda et al., 2013), also following the manufacturer's recommendation (Table 1).

Diets were prepared as follows: Ingredients were mixed for $10 \mathrm{~min}$ in a Kitchen Aid mixer, water (30\%) was incorporated, and the mixing continued for an additional $15 \mathrm{~min}$. The wet diet mash was processed through a meat grinder (fitted with a $1.6 \mathrm{~mm}$ diameter-hole die) at a passage rate of $40 \mathrm{~kg} \mathrm{~min}^{-1}$ while keeping the temperature between $70-75^{\circ} \mathrm{C}$. The spaghetti-like strands were placed to dry in a convection oven at $100{ }^{\circ} \mathrm{C}$ for $8 \mathrm{~min}$ and allowed to cool and dry overnight at room temperature before packing. The approximate composition of the experimental diets was assessed by using standard procedures (AOAC, 2006). The aflatoxin concentration (B1, B2, G1, and G2) was analyzed by HPLC on both non-contaminated and aflatoxin-contaminated control diets at Trilogy Analytical Laboratory (Washington, M0). Additionally, these diets were also tested for deoxynivalenol, fumonisin (B1, B2, and B3), ochratoxin A, and T-2 toxin at the same location. 
Table 1. Composition of all experimental diets ( $\mathrm{g} \mathrm{kg}$-1as is) for Litopenaeus vannamei juveniles.

\begin{tabular}{|c|c|c|c|c|c|}
\hline & CD diet & UCD diet & CD diet + Aflabalan $®$ & CD diet + Mycofix plus $\circledR$ & CD diet + Mycosorb $®$ \\
\hline Wheat meal & 427.95 & 439.83 & 425.95 & 425.45 & 425.95 \\
\hline Fish meal & 384.41 & 384.63 & 384.41 & 384.41 & 384.41 \\
\hline Soybean lecithin & 19.93 & 19.00 & 19.93 & 19.93 & 19.93 \\
\hline Contaminated corn & 11.11 & - & 11.11 & 11.11 & 11.11 \\
\hline Cholesterol solvay & 0.20 & 0.15 & 0.20 & 0.20 & 0.20 \\
\hline Constant ingredients* & 156.40 & 156.40 & 156.40 & 156.40 & 156.40 \\
\hline Aflabalan $®$ & - & - & 2.00 & - & - \\
\hline Mycofix plus $®$ & - & - & - & 2.50 & - \\
\hline Mycosorb $®$ & - & - & - & - & 2.00 \\
\hline Total & 1000.00 & 1000.00 & 1000.00 & 1000.00 & 1000.00 \\
\hline
\end{tabular}

$\mathrm{CD}=$ contaminated diet, $\mathrm{UCD}=$ uncontaminated diet

${ }^{*}$ Constant ingredients: soybean meal $80 \mathrm{~g} \mathrm{~kg}^{-1}$, shrimp meal $40 \mathrm{~g} \mathrm{~kg}^{-1}$, fish oil $19 \mathrm{~g} \mathrm{~kg}^{-1}$, sodium alginate $10 \mathrm{~g} \mathrm{~kg}^{-1}$, vitamin mixture $3.5 \mathrm{~g} \mathrm{~kg}^{-1}$, mineral mixture $2.5 \mathrm{~g}$ $\mathrm{kg}^{-1}$, antioxidant $0.5 \mathrm{~g} \mathrm{~kg}^{-1}$, mold inhibitor $0.5 \mathrm{~g} \mathrm{~kg}^{-1}$, vitamin C $0.2 \mathrm{~g} \mathrm{~kg}^{-1}$, vitamin E $0.2 \mathrm{~g} \mathrm{~kg}^{-1}$.

Growth trial conditions and feeding protocol. A feeding trial was carried out in a closed recirculation system containing artificial seawater. The experimental facility had an array of $60-\mathrm{L}$ fiberglass tanks. Each one of these was continuously fed with synthetic marine water (Fritz ${ }^{\circledR}$, Dallas, TX, USA) using a $350 \mathrm{~mL} \mathrm{~min}{ }^{-1}$ flow-through rate. Each tank is equipped with an air-water lift system for internal recirculation. The facility is designed to account for possible water-quality fluctuations that may simultaneously affect all tanks. Salinity and temperature were measured daily, whereas $\mathrm{pH}$, total ammonia, nitrites, and nitrates were recorded weekly: salinity $31 \pm 3 \mathrm{~g} \mathrm{~L}^{-1}$, temperature $29 \pm 1^{\circ} \mathrm{C}, \mathrm{pH} 8.1 \pm 0.1$, total ammonia $0 \mathrm{mg} \mathrm{L}^{-1}$, nitrites $0.2 \pm 0.1 \mathrm{mg} \mathrm{L}^{-1}$, and nitrates $40 \pm 15 \mathrm{mg}$ $\mathrm{L}^{-1}$ (mean \pm standard deviation). During this study, these parameters were within the optimum values for shrimp. Juvenile white shrimp $L$. vannmaei were obtained from the Langostinos y Camarones de Oriente Laboratory, Boca del Río, Veracruz, Mexico. Upon arrival at our facilities, the shrimp were acclimatized for one week in $500 \mathrm{~L}$ holding tanks with the conditions prevailing at the bioassay room, before the growth test. Shrimp were individually weighed on a digital scale after blotting off excess water with a wet cloth. Over the first three days after distributing the animals, dead shrimp were replaced by others taken from a pool of animals fed with the same diet. A photoperiod was set in order to provide $12 \mathrm{~h}$ of light and $12 \mathrm{~h}$ of dark. Shrimp were fed twice daily to achieve an apparent satiation (50\% of the portion at 9:00 and 17:00) for 42 days. Any feed remaining in the tank was removed by siphoning before performing the feeding. During the first 2 days, daily feeding was fixed at $10 \%$ of the biomass inside the tanks and subsequently adjusted to allow a small excess of remaining feed in each tank until the next feeding. The previously weighed feed strands were fragmented into small pieces for each feeding period in order to ensure a sufficient amount of pellets per shrimp.

Assessment of growth performance parameters. The shrimp in each tank were individually weighed at 7-day intervals in order to assess growth and adjust the feeding ratios. Survival and feed intake were recorded daily and the feeding ratios were adjusted after considering the amount of shrimp per tank and the remaining feed on the latter. The following variables were evaluated: weight gain $(\%)=[$ (mean individual final weight (g) - mean individual initial weight (g)) / mean individual initial weight $(\mathrm{g})] \times 100$. Feed intake $\left(\mathrm{g}\right.$ shrimp ${ }^{-1} 42$ days $\left.^{-1}\right)=($ amount of feed provided - remaining feed)/amount of shrimp. Feed conversion ratio $=$ feed intake $(\mathrm{g}) /$ live weight gain $(\mathrm{g})$. Survival $(\%)=$ (amount of surviving shrimp/initial amount of shrimp) $\times 100$. When the experiment began, a pooled shrimp sample was taken to determine the initial moisture and nitrogen content. After concluding the experiment, five shrimp per tank were randomly sampled to estimate final moisture and nitrogen content. Shrimp samples were freeze-dried, ground in a coffee grinder, and stored until further analysis. Nitrogen retention efficiency (NRE \%) was estimated as follows: NRE $=[($ final mean body weight $(\mathrm{g}) *$ final crude protein content on carcass $(\%)$ ) - (initial mean body weight $(\mathrm{g}) *$ initial crude protein content on carcass (\%)) / amount of crude protein consumed $(\mathrm{g})] * 100$.

Statistical analysis. The results are presented as means \pm standard deviations. Average body weights per tank were used to calculate growth rates and feed-conversion ratios. Weights, feed intake, growth rate, feed-conversion ratio, survival, and nitrogen retention efficiency were analyzed by a one-way ANOVA comparing the experimental diets and subsequently by a Tukey's multiple range test ( $\alpha=0.05$, SSPS 16.0, 2007, SPSS Inc., Chicago, Illinois).

\section{RESULTS}

Experimental diets. The chemical composition of all test diets was similar among treatments: crude protein, crude lipids, and ash content (on a dry weight basis) ranged between 39 and $40 \%, 8.3$ and $9.0 \%$, and 8.6 and $9.0 \%$, respectively. Aflatoxin concentration in all contaminated diets was $75 \mu \mathrm{g} \mathrm{kg}^{-1}$ and the predominant aflatoxin type was B1 (60.7 $\left.\mu \mathrm{g} \mathrm{kg}^{-1}\right)$, followed by B2 $\left(9.7 \mu \mathrm{g} \mathrm{kg}^{-1}\right)$, and G1 $(4.3 \mu \mathrm{g} \mathrm{kg}-1)$. Concentrations of other mycotoxins in all contaminated diets was below the detection limit. In all non-contaminated diets, mycotoxin levels were also below detection limits. 


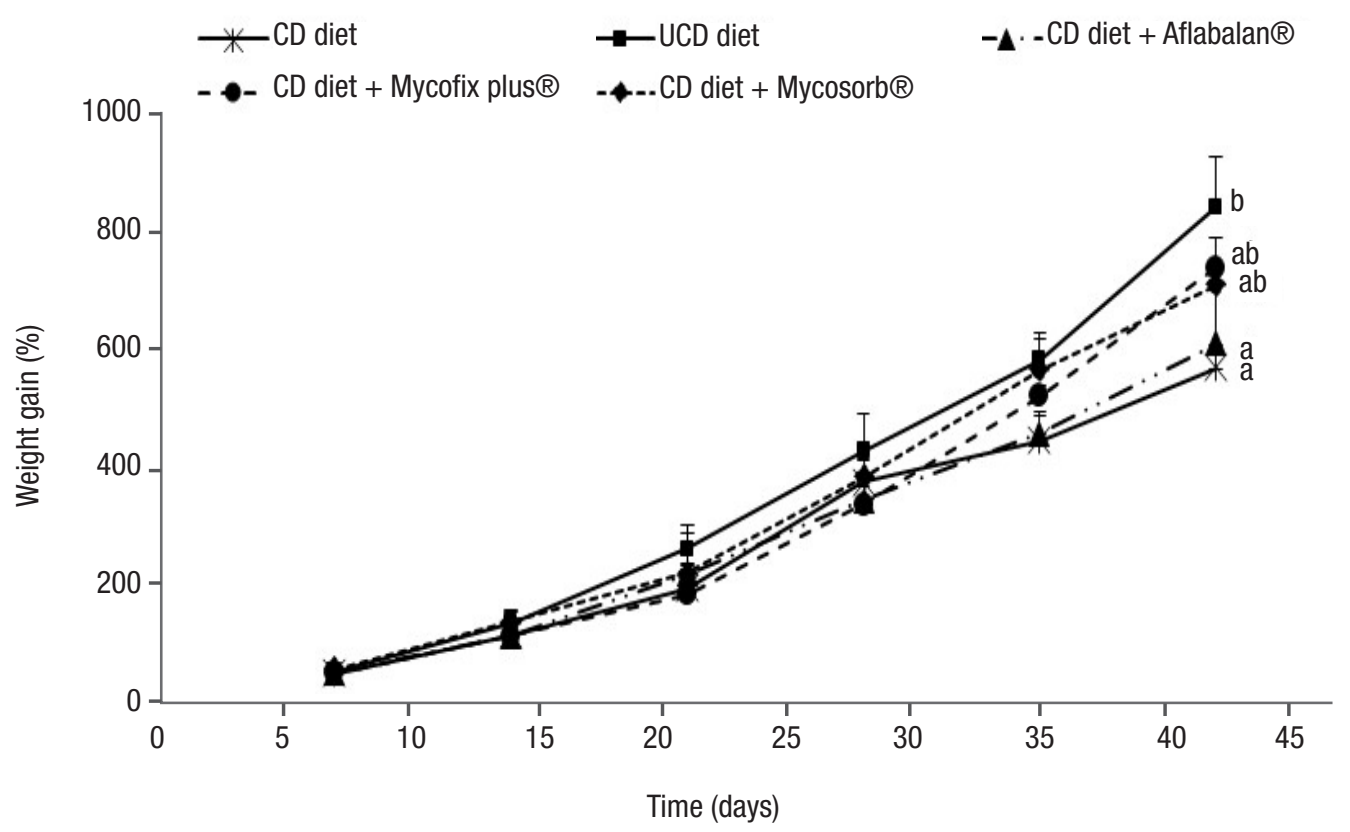

Figure 1. Growth rate in shrimps (Litopenaeus vannamel) fed with aflatoxin-contaminated diets. Each point represents the mean value of four replicates tanks along with its standard deviation. Different letters show significant differences $(p<0.05) . C D=$ contaminated diet, UCD $=$ uncontaminated diet

Growth performance parameters. The results obtained after measuring growth, feed intake, and nitrogen-retention efficiency are shown in Figures 1, 2, and 3. The growth rate was similar when diets were compared after 35 days. However, after concluding the experiment, shrimp fed with contaminated diets showed a significantly decreased growth rate $(32 \%$ less), when compared to those fed with uncontaminated diets. The supplementation of Aflabalan $®$ resulted in similar growth rates in comparison to those measured after supplementing a contaminated diet, whereas Mycosorb $₫$ and Mycofix plus $₫$ supplemented diets exhibited higher growth rates (24-29\%) when compared to shrimp fed with contaminated diets, although they were not statistically different. Shrimp fed with contaminated diets exhibited a significantly decreased feed intake from day 28 to the end of the experiment. After this, the latter parameter decreased by $29 \%$. The supplementation of Aflabalan $\circledast$ and Mycofix plus $®$ to contaminated diets did not counteract the decreased feed intake caused by the presence of aflatoxins. The addition of Mycosorb $尺$ to these diets resulted in higher feed intake when compared to those shrimp fed with contaminated diets, although the results were not significantly different. The addition of contaminated grains or aflatoxin binders did not affect the feed-conversion ratio by the end of the experiment. These ranged between 1.2 and 1.3 when the different diets were compared. The survival of shrimp fed with contaminated diets was slightly lower when compared to those fed with the other experimental diets (80 versus 88 - 93\%), although differences were not significantly different. The addition of aflatoxin-contaminated corn to the diets decreased nitrogen retention efficiency by $32 \%$ and when commercially available aflatoxin commercial binders were tested, they did not improve nitrogen-retention efficiency.

\section{DISCUSSION}

Dietary aflatoxin supplementation to shrimp. Contamination by aflatoxins of diets manufactured for aquaculture is one of the most important problems currently challenging the shrimp-farming industry caused by increasing levels of plant-derived ingredients in aqua feeds (Santos et al., 2010; Anater et al., 2016). Feeding shrimp with diets contaminated by pure aflatoxin (Suppadit et al., 2006; Arunlertaree et al., 2007; Zeng et al., 2015) or with contaminated grains (Tapia-Salazar et al., 2012; García-Pérez et al., 2013) has resulted in lower feed intake, scarce weight gain, and, occasionally, in mortality and immune system deterioration. The results observed in this study regarding growth rates, feed intake, feed-conversion ratio, nitrogen retention and the survival of shrimp $L$. vannamei fed with diets containing low aflatoxin levels are in accordance with previously obtained results. Tapia-Salazar et al. (2012) and García-Pérez et al. (2013) point out that a significantly reduced feed intake and weight may occur without affecting survival because of the synergic effect induced by low aflatoxins levels (B1, B2, G1, and G2). In this study, the overall dietary aflatoxin was $75 \mu \mathrm{g} \mathrm{kg}^{-1}$, and aflatoxin B1 $\left(60.7 \mu \mathrm{g} \mathrm{kg}^{-1}\right)$ was the predominant type, followed by B2 $\left(9.7 \mu \mathrm{g} \mathrm{kg}^{-1}\right)$ and G1 $\left(4.3 \mu \mathrm{g} \mathrm{kg}^{-1}\right)$. The results obtained in this study confirm that a combination of aflatoxins at low levels impairs shrimp's performance. The lack of effect on the survival rates of shrimp associated with low inclusion levels in their diet is in line with previous results observed for shrimp fed with low levels of pure aflatoxin (Gopinath \& Raj, 2009; Zeng et al., 2015) or naturally contaminated grains (Tapia-Salazar et al., 2012; García-Pérez et al., 2013). The background information on the effect of dietary aflatoxin on nitrogen retention in shrimp is scarce. In this study, 
a significant decrease of nutrient-retention efficiency (30\%) was observed when shrimp were fed with aflatoxin-contaminated diets; this agrees with the results published by Zeng et al. (2015), as they reported a significant decrease of crude protein (approximately $6 \%$ ) and crude lipids (approximately 27\%) in whole $L$. vannamei carcasses previously fed with increasing levels of pure aflatoxin. Studies have shown that aflatoxin consumption causes hepatotoxicity, inhibits protein synthesis, and causes immunosuppression and metabolic alterations (Monson et al., 2015). This effect is enhanced by a reduced feed intake. The lower nutrient retention observed in shrimp fed with aflatoxin-contaminated diets was probably caused by several complications derived from dysfunctional metabolic processes during aflatoxicosis.

Efficiency of aflatoxin-binding agents in reducing aflatoxicosis in shrimp. In farm animals, the addition of absorbing or biotransforming agents to diets is a strategy designed to counteract the negative effects caused by the consumption of mycotoxins (Surai \& Dvorska, 2005; Kolosova, \& Stroka, 2011; Gowda et al., 2013; Wielogórska et al., 2016). Some of the commercially available mycotoxin-binding products possess a formulation consisting of multiple sequestering components (antioxidants, probiotics, yeast and/or plants, among others) that contribute more effectively to decreasing most of the effects caused by mycotoxin consumption, such as decreases of growth, feed intake, the production of reactive oxygen species, lipid peroxidation processes, the impairment of enzymes involved in different metabolic processes (digestion, immune system etc.) (Surai \& Dvorska, 2005; Oguz et al., 2011; Wielogórska et al., 2016). However, their effectiveness depends on several factors such as specificity towards some mycotoxins and their concentration levels, their presence as a pure compound or as a mixture, $\mathrm{pH}$, the clay source, absorption/desorption ability, etc. (Devreese et al., 2013; De-Mil et al., 2015; Wielogórska et al., 2016). Regarding terrestrial animals, products are already available for preventing or correcting the negative effects caused by mycotoxin-contaminated feed when suitable levels are used (Surai \& Dvorska, 2005; Boudergue et al., 2009; Kolosova, \& Stroka, 2011; Gowda et al., 2013; Wielogórska et al., 2016). One of the problems faced by the aquaculture industry regarding the effectiveness of commercial products intended to decrease aflatoxicosis in aquatic organisms is the limited amount of available information. Often the inclusion levels used for testing are those obtained for other species. In this study, as no information on Aflabalan ${ }^{\circledR}$ was available for other species, the inclusion levels consisted of a $2 \mathrm{~g}$ $\mathrm{kg}^{-1}$ preventive dose based on the manufacturer's recommendations. A $2 \mathrm{~g} \mathrm{~kg}^{-1}$ corrective dose of Mycosorb $®$ was used because inadequate results were observed on terrestrial animals when it was included in aflatoxin-contaminated diets at levels ranging between 0.5 and $1.5 \mathrm{~g}$ $\mathrm{kg}^{-1}$. Finally, a $2.5 \mathrm{~g} \mathrm{~kg}^{-1}$ level of Mycofix plus $®$ was selected as optimal results were observed on terrestrial animals fed with aflatoxincontaminated diets. The results obtained in this study showed that after feeding shrimp with an aflatoxin-contaminated diet supplemented with $2 \mathrm{~g} \mathrm{~kg}^{-1}$ Aflabalan $\circledast$, similar growth rates were obtained in comparison to those fed with non-contaminated diets (control diets). The addition of Mycosorb $₫$ and Mycofix-plus $®$ slightly improved these parameters, although they were not significantly similar when compared to shrimp fed with non-contaminated diets. After comparing the ingredients of all test products, it was noted that Mycosorb® contains glucomannan cell walls from $S$. cerevisiae and cell walls from microalga, whereas Mycofix plus $®$ contains bentonite, plant extracts, and some yeast or bacterial species purportedly useful for detoxifying several mycotoxins. Studies on broilers and rats have shown that some of these additives reverted some of the negative effects caused by the presence of mycotoxins (Politis et al., 2005; Abdel-Wahhab et al., 2006; Manoharan et al., 2008).

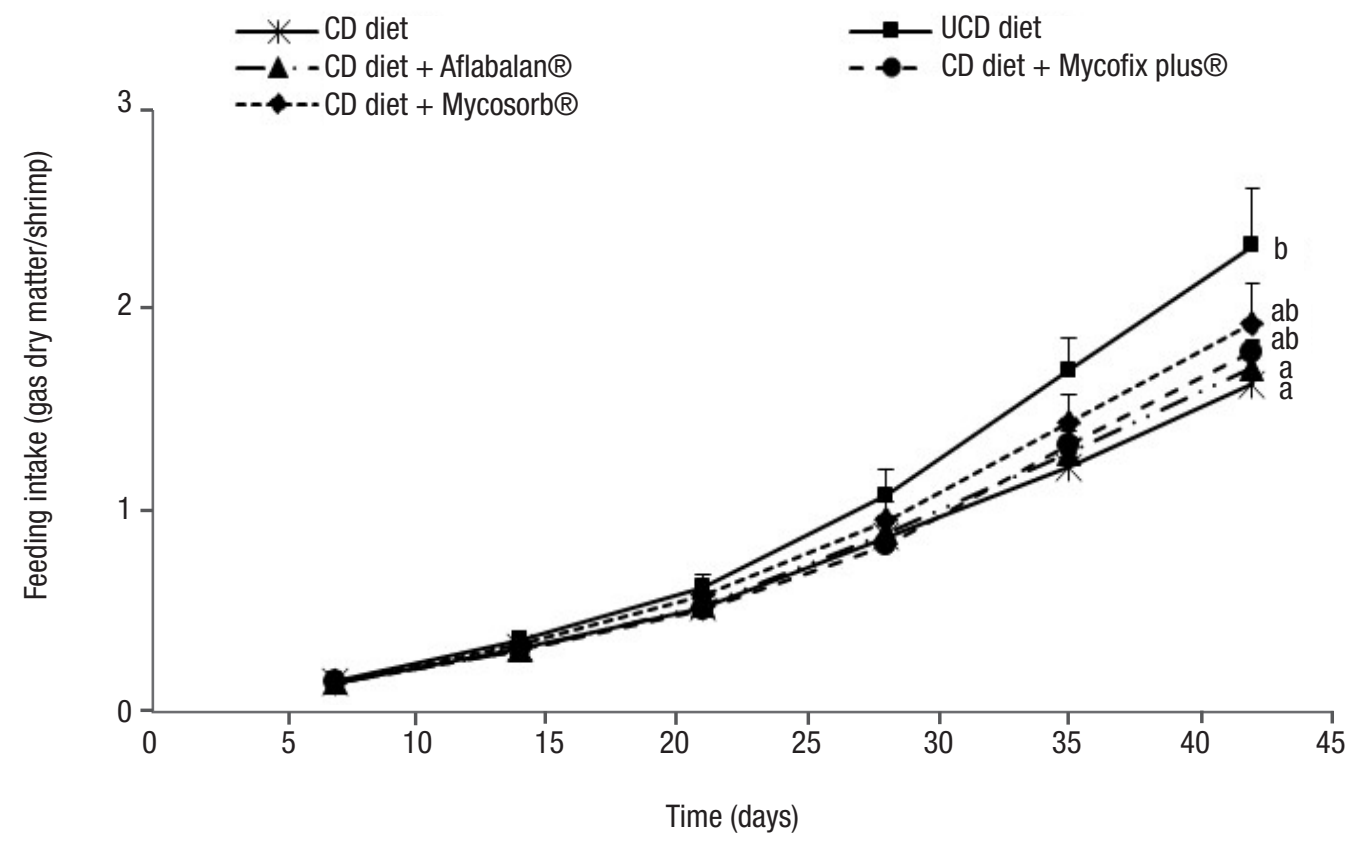

Figure 2. Feed intake in Litopenaeus vannamei juveniles fed with aflatoxin-contaminated diets. Each point represents the mean value of four replicates tanks along with its standard deviation. Different letters show significant differences $(p<0.05) . C D=$ contaminated diet, UCD $=$ uncontaminated diet. 


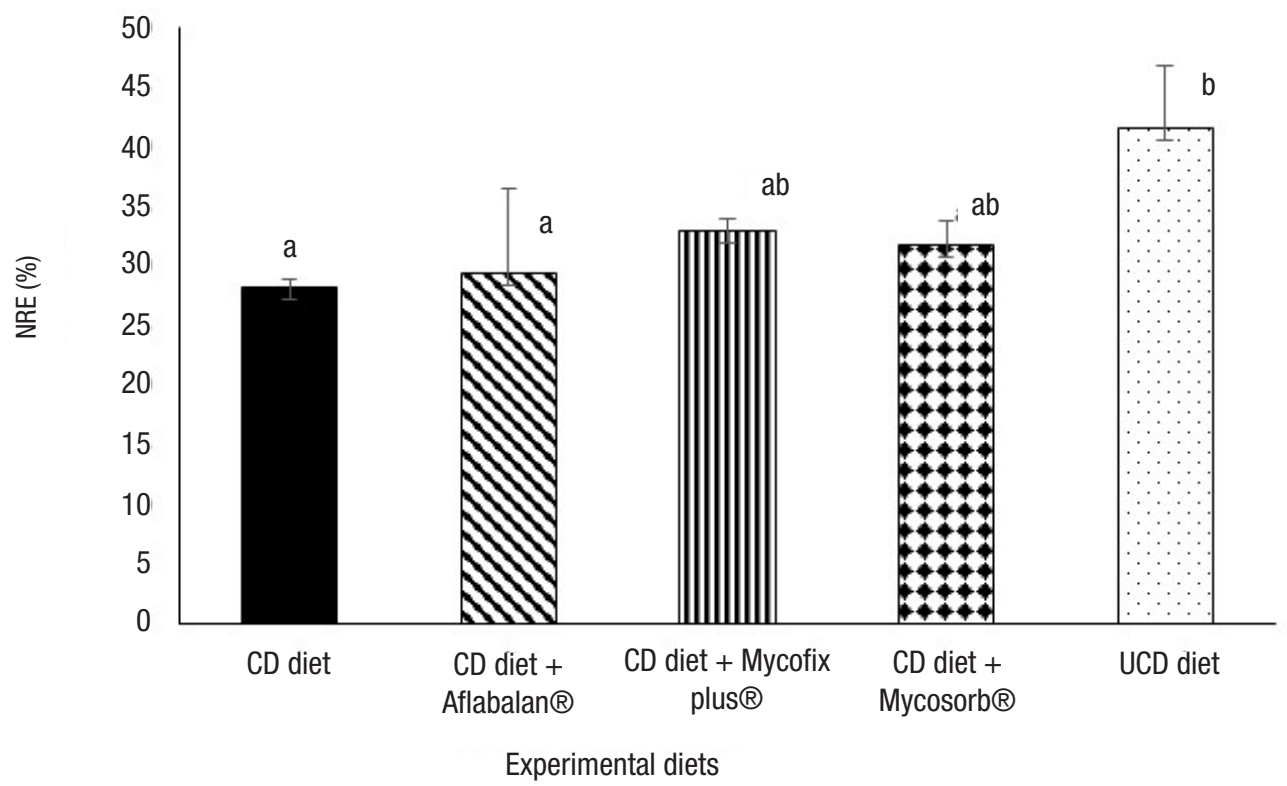

Figure 3. Nitrogen retention efficiency (NRE) in Litopenaeus vannamei juveniles fed with aflatoxin-contaminated diets. Each point represents the mean value of four replicates tanks per treatment. Different letters show significant differences $(p<0.05)$. CD $=$ contaminated diet, $U C D=$ uncontaminated diet.

Despite the fact that positive results were obtained by including these additives on other species fed with mycotoxin-contaminated feed, this was not the case for shrimp. The different results may be explained by several factors such as the respective supplemented levels. More studies are needed in order to test higher levels that may counteract the effects of aflatoxicosis in shrimp.

We conclude that after feeding a juvenile population of the Pacific white shrimp $L$. vannamei diets that contain low aflatoxin levels, they had a significantly reduced growth rate, feed intake, and nitrogenretention efficiency, but their survival and feed conversion ratio were not affected. Feeding juvenile $L$. vannamei with aflatoxin-contaminated diets supplemented with Aflabalan $\circledast$, Mycosorb $®$ and Mycofix plus $®$ at any of the levels we tested in this study did not reproduce the growth performance observed on shrimp fed with non-contaminated diets.

\section{ACKNOWLEDGEMENTS}

Consejo Nacional de Ciencia y Tecnologia (CONACyT 2007-01-83000) and Programa de Apoyo a la Investigación Científica y Tecnológica (PAICYTUANL) granted financial support. We would like to thank "Langostinos y Camarones" shrimp hatchery (Boca del Río, Veracruz, Mexico) for providing the shrimp to carry out the growth test. The NuteK company (Tehuacán, Puebla, Mexico) is acknowledged for providing contaminated corn. Animal handling and sample collection were performed in accordance to institutional, national, and international guidelines and regulations.

\section{REFERENCIAS}

Abdel-Wahhab, M. A., H. H. Ahmed \& M. H. Hagazl. 2006. Prevention of aflatoxin B1-initiated hepatotoxicity in rat by marine algae extracts. Journal of Applied Toxicology 26: 229-238. D0I: 10.1002/jat.1127
Anater, A., L. Manyes, G. Meca, E. Ferrer, F. L. Bittencourt, C. Turra-Pimpão \& G. Font. 2016. Mycotoxins and their consequences in aquaculture: A review. Aquaculture 451: 1-10. DOl: 10.1016/j.aquaculture.2015.08.022.

a0AC (Association of Official Analytical Chemists). 2006. Official Methods of Analysis of AOAC International. 18 ${ }^{\text {th }}$ Ed. Association of Analytical Chemistry, Mary Land, USA.

Arana, S., V. A. Alvesm, M. Sabino, Y. A. Tabata, S. Nonogaki, M. L. Zaidan-Dagl \& F. J. Hernandez-Blazquez. 2011. Evaluation of the efficacy of hydrated sodium aluminosilicate in the prevention of aflatoxin-induced hepatic cancer in rainbow trout. Pesquisa Veterinária Brasileira 31 : 751-755. DOI: 10.1590/S0100-736X2011000900005

Arunlertaree, C., L. Soonngam and R. Hutacharoen. 2007. Vermiculite and hydrated sodium calcium aluminosilicates as the agent of Aflatoxin B1 absorption for black tiger shrimp diets. Environment and Natural Resources Journal 5 (1): 50-58.

Binder, E. M., D. Heidler, G. Schatzmayr, N. Thimm, E. Fuchs, M. Schuh, R. KRSKA, \& J. BINDER. 2001. Microbial detoxification of mycotoxins in animal feed. 2001. In: de Koe, W. J., R. A. Samson, H. P. van Egmond, J. Gilbert \& M. Sabino (Eds.) Mycotoxins and Phycotoxins in Perspective at the Turn of the Millennium. Proceedings of the 10th International IUPAC Symposium on Mycotoxins and Phycotoxins, Guaruja, Brazil. pp. 271-277.

Boudergue, C., Ch. Burel, S. Dragacci, M. Ch. Favrot, J. M. Fremy, C. Massimi, P. Prigent, P. Debongnie, L. Pussemier, H. Boudra, D. Morgavi, I. Oswald, A. Perez \& G. Avantaggiato. 2009. Review of mycotoxin detoxifying agents used as feed additives: mode of action, efficacy, and feed/ food safety. Scientific report submitted to EFSA. 192 p. Reference 
number of the call for proposal: CFP/EFSA/FEEDAP/2009/01. DOI: 10.2903/sp.efsa.2009.EN-22

Cheng, G., H. Hao, S. XIE, X. Wang, M. Dal, L. Huang \& Z. Yuan. 2014. Antibiotic alternatives: the substitution of antibiotics in animal husbandry? Frontiers in Microbiology 5: 1-15. DOI: 10.3389/fmicb.2014.00217

De-Mil T., M. Devreese, S. De-Baere, E. Van-Ranst, M. Eeckhout, P. De-Backer \& S. Croubels, S. 2015. Characterization of 27 mycotoxin binders and the relation with in vitro zearalenone adsorption at a single concentration. Toxins 7: 21-33. DOI: 10.3390/toxins7010021

Devreese, M., P. De Backer \& S. Croubles. 2013. Different methods to counteract mycotoxin production and its impact on animal health. Vlaams Diergeneeskundig Tijdschrift 82: 181-190. Available on line at: https://biblio.ugent.be/publication/4125573

El-Barabay. M. I. \& A. I. Mehrim. 2009. Protective effect of antioxidant medicinal herbs, Rosemary and Parsley, on subacute aflatoxicosis in Nile Tilapia 0. niloticus. Journal of Fisheries and Aquatic Science 4: 178-190. DOI: 10.3923/jfas.2009.178.190

García-Pérez, 0. D., M. Tapia-Salazar, M. G. Nieto-López, D. Villarreal-Cavazos, L. E. Cruz-Suárez \& D. Ricque-Marie. 2013. Effectiveness of aluminosilicate-based products for detoxification of aflatoxin-contaminated diets fed to pacific white shrimp Litopenaeus vannamei juveniles. Ciencias Marinas 39: 1-13. D0I: 10.7773/cm.v39i1.2165

Gopinath, R. \& R. P. Ras. 2009. Histological alterations in the hepatopancreas of Penaeus monodon Fabricius (1798) given aflatoxin B1-incorporated diets. Journal of Aquaculture Research 40: 1235-1242. DOI: 10.1111/j.1365-2109.2009.02207.x

Gowda N. K. S., Swamy H. V. L. N. \& P. Mahajan. 2013. Recent advances for control, counteraction and amelioration of potential aflatoxins in animal feeds. In: Razzaghi-Abyaneh M. (Ed.). Aflatoxins: Recent advances and future prospects. InTech, pp. 129-140. D0l: $10.5772 / 51779$

Hauptman, B. S., F. T. Barrows, S. S. Block, T. G. Gaylord, Paterson J. A. \& W. M. Sealey. 2014. Potential for a mycotoxin deactivator to improve growth and performance of rainbow trout fed high levels of an ethanol industry co-product, grain distiller's dried yeast. North American Journal of Aquaculture 76: 297-304. D0I: $10.1080 / 15222055.2014 .902891$

Kolosova, A. \& J. Stroka. 2011. Substances for reduction of the contamination of feed by mycotoxins: a review. World Mycotoxin Journal 4: 225-256. DOI: 10.3920/WMJ2011.1288

Mahfouz, M. E. 2015. Ameliorative effect of curcumin on aflatoxin B1 induced changes in liver gene expression of Oreochromis niloticus. Molecular Biology 49: 275-286. DOI 10.1134/S0026893315020089

Molnar, 0., G. Schatzmayr, E. Fuchs \& H. Prillinger. 2004. Trichosporon mycotoxinivorans sp. nov., A new yeast species useful in biological detoxification of various mycotoxins. Systematic and Applied Microbiology 27: 661-671. DOI 10.1078/0723202042369947
Manoharan, N., P. Sampathkumar, B. Dheeba, S. Sheikabdulla, G. Vinothprasanna, R. Vinothkannan, S. Kalavathy, A. Viuayaanand \& A. ShanmugasunDARAM. 2008. Potential hepatoprotective effect of aqueous extract of Gracilaria corticata in AFB1 induced hepatotoxicity in wistar rats. Journal of Biological Sciences 8: 1352-1355. D0I: 10.3923/ jbs.2008.1352.1355

Mohapatra, S., N. P. Sahu, A. K. Pal, A. K. Prusty, V. Kumar \& S. Kumar. 2011. Haematoimmunology and histoarchitectural changes in Labeo rohita fingerlings: effect of dietary aflatoxin and mould inhibitor. Fish Physiology and Biochemistry 37: 177-186. D0I: 10.1007/s10695010-9428-1.

Monson, M. S., R. A. Coulombe \& K. M. Reed. 2015. Aflatoxicosis: lessons from toxicity and responses to aflatoxin B1 in poultry. Agriculture 5: 742-777.

Oguz, H., F. Nizmlioglu, I. Dinc, K. Uney \& H. Aydin. 2011. Determination of aflatoxin existence in mixed feed wheat flour and bulgur samples. Eurasian Journal of Veterinary Sciences 27:171-175. DOI: 10.3390/ agriculture5030742

Politis I., K. Fegeros, S. Nitsch, G. Schatzmayr \& D. Kantas. 2005. Use of Trichosporon mycotoxinivorans to suppress the effects of ochratoxicosis on the immune system of broiler chicks. British Poultry Science 46: 58-65. D0I: 10.1080/00071660400023904

Ringø, E., J. E. Olsen, J. L. G. Vecino, S. Wadsworth \& S. Y. Song. 2012. Use of immunostimulants and nucleotides in aquaculture: a review. Journal of Marine Science: Research \& Development 2: 1-22. D0I: 10.4172/2155-9910.1000104

Saho0, P. K., S. C. Mukher.ee, A. K. Jain \& A. Mukherjee. 2003. Histopathological and electron microscopic studies of gills and opisthonephros of Rohu, Labeo rohita to acute and subchronic aflatoxin B1 toxicity. Asian Fisheries Science 16: 257-268.

Santos, G. A., I. Rodrigues, K. Naehrer \& P. Encarnaca0. 2010. Mycotoxins in aquaculture: 0 ccurrence in feed components and impact on animal performance. Aquaculture Europe 35: 6-10. Available on line at: http://www.uanl.mx/utilerias/nutricion_acuicola/X/archivos/19SantosGoncalo.pdf

Selim, K. M., H. El-Hofy \& R. H. Khall. 2014. The efficacy of three mycotoxin adsorbents to alleviate aflatoxin B1-induced toxicity in Oreochromis niloticus. Aquaculture International 22: 523-540. D0I: 10.1007/s10499-013-9661-6

Suppadit, T., S. Jaturasitha \& N. PriPWAl. 2006. Utilization of hydrated sodium calcium aluminosilicate and vermiculite for aflatoxin B1 adsorption in pacific white shrimp (Litopenaeus vannamei) diets. Journal of Applied Animal Research 29: 129-132. D0l: 10.1080/09712119.2006.9706587

SuRAl, P. F. \& J. E. DvorsKa. 2005. Effects of mycotoxins on antioxidant status and immunity. In: Diaz D. E. (Ed). The Mycotoxin Blue Book. Nottingham University Press, Nottingham, pp. 93-137. 
Tapia-Salazar, M., 0. D. García-Pérez, R. A. Velásquez-Soto, M. G. Nieto-López, D. Villarreal-Cavazos, D., Ricque-Marie \& L. E. Cruz-Suarez. 2012. Growth, feed intake, survival and histological response of white shrimp L. vannamei fed diets containing grains naturally contaminated with aflatoxin. Ciencias Marinas 38: 491-504. D0I:10.7773/ cm.v38i3.2094

Tapia-Salazar, M., García-Pérez, 0. D., Nieto-López, M., Ricque-Marie, D., Villarreal-Cavazos, D., \& L. E. Cruz-Suárez. 2010. Uso de secuestrantes para disminuir la toxicidad de micotoxinas en alimentos para acuacultura. In: Cruz-Suarez, L. E., Ricque-Marie, D., Tapia-Salazar, M., Nieto-López, M.G., Villarreal-Cavazos, D. A. \& J. Gamboa-Delgado (Eds.). Avances en Nutrición Acuícola. X -Memorias del Décimo Simposio Internacional de Nutrición Acuícola, 8-10 de noviembre,
San Nicolás de los Garza, N. L., México. ISBN 978-607-433-5460 . Universidad Autónoma de Nuevo León, Monterrey, México, pp. 514-546.

WielogórsKa, E., S. Macdonald \& C. T. ElLIOTt. 2016. A review of the efficacy of mycotoxin detoxifying agents used in feed in light of changing global environment and legislation. World Mycotoxin Journal 9 (3): 419-433. DOI: 10.3920/WMJ2015.1919

Zeng S. L., W. Q. Long, L. X. Tian, S. W. Xie, Y. J. Chen, H. J. Yang \& Y. J. LIU. 2015. Effects of dietary aflatoxin B1 on growth performance, body composition, haematological parameters and histopathology of juvenile Pacific white shrimp (Litopenaeus vannemei). Journal of Aquaculture Nutrition: 1-8. D0I: 10.1111/anu.12331 